\title{
Exploring the dynamics of English/Spanish codeswitching in a written corpus
}

\author{
M Isabel González Cruz \\ Universidad de Las Palmas de Gran Canaria \\ isabel.gonzalezcruz@ulpgc.es
}

\begin{abstract}
This investigation is part of a much larger ongoing research project which approaches a corpus of popular romance fiction novels from a multidisciplinary perspective. The paper focuses on the usage of Spanish words and expressions in the English written discourse of two samples of romances taken from the corpus we are compiling for Research Project FFI2014-53962-P. When analyzing the occurrences of Hispanicisms in the samples, we will specifically address the issues of both their forms and the different socio-pragmatic functions that these cases of language switching seem to play. It is only recently that scholars have studied the patterns of codeswitching in literary writing, but, to the best of the author's knowledge, no previous research has focused on codeswitching in this particular subgenre, which has always been doubly stigmatized for being both popular and feminine.
\end{abstract}

Keywords: English/Spanish codeswitching, written codeswitching, Hispanicisms, popular romance fiction, Canary Islands

\section{Introduction}

This paper is part of a much larger ongoing research project ${ }^{1}$ which approaches a corpus of romance fiction novels from a multidisciplinary perspective. The present study focuses on one particular aspect of the four levels of analyses established for that 
investigation, namely, the incorporation of Spanish words and expressions into their English written discourse. We will examine a total of 16 romances taken from the corpus that is being compiled for Project FFI2014-53962-P in order to specifically explore the dynamics of English/Spanish codeswitching, focusing on both their types and the socio-pragmatic or discourse functions that these cases of language mixing ${ }^{2}$ seem to play.

Mixed-language written texts have frequently been found in postcolonial writing and travel literature (Curell and de Uriarte, 2001; González-Cruz and González de la Rosa 2006, 2007; Curell et al. 2009; Anchimbe and Janne, 2011; González-Cruz, 2013). It is only relatively recently that scholars have shown an interest in studying the patterns of codeswitching in other types of literary writing. In fact, in the last decades a number of authors have investigated this phenomenon in a variety of genres, such as narrative (Cortés-Conde and Boxer, 2002), plays and drama (Pfaff and Cháves, 1986; Anderson, 2004; Jonsson, 2010), poetry (Valdés-Fallis, 1976; 1977), short stories (MontesGranados, 2012) or even stand comedy (Woolard, 1987) and TV series (GiménezEguibar and de los Heros, forthcoming). Other works have focused on areas such as the cyberspace (Montes Alcalá, 2005b; Söderqvist, 2009) and popular music (Flores Ohlson, 2008), while authors like Montes-Alcalá (2016) have carried out comparative research about the use of codeswitching in different genres. To the best of our knowledge, no previous research has focused on codeswitching in popular romance fiction novels, a sub-literary form that has always been doubly stigmatized for being both popular and female-oriented (Sánchez-Palencia, 1997). As indicated in the title, our aim here is to explore the dynamics of the use of Hispanicisms in this type of English fictional texts.

The paper is structured as follows. After the introductory section, we will approach the theoretical framework from which we draw on, namely the sociolinguistic study of language codeswitching. With an overview of this field of research we will shape up the socio-pragmatic analysis of the use of Hispanicisms in the selected samples as cases of codeswitching. The novels are briefly depicted in section 3, where the hypothesis and the methodological procedure are also outlined. Section 4 describes the data obtained after analyzing the occurrences of Spanish words and expressions in the texts. First we will focus on their formal types and then we will discuss the kind of functions these Hispanicisms seem to perform. Some concluding remarks will be offered before listing the bibliographical references, which also include the primary sources used.

\section{Theoretical framework. On codeswitching}

Language switching is one of the most salient manifestations of bilingualism and language contact situations, which involve the alternative use of two (or more) languages. The term codeswitching, also spelled code-switching (henceforth, CS), was used by Haugen ${ }^{3}$ (1956) in order to refer to situations in which "a bilingual introduces a completely unassimilated word from another language into his speech" (Haugen, 1956: 40). Defined simply as the alternating use of two languages or language varieties in the 
same stretch of discourse, at the word, clause or sentence level, CS is viewed as "a natural phenomenon commonly attested in speakers of bilingual communities in which two or more languages are in contact" (Montes-Alcalá, 2001: 715). Actually, CS is fostered by bilingualism, which is a prerequisite to CS, since it is when bilingual speakers converse that they tend to "integrate linguistic material from both of their languages within the same discourse segment" (Bonvillain, 2008: 320). Far from being a random mixing of two languages indicating a speaker's internal mental confusion, as it used to be thought of decades ago, CS is now taken to reflect "a skillful manipulation of two language systems for various communicative functions" (Bullock and Toribio, 2009: 4). In fact, it has become an increasingly important field of research and has been the concern of disciplines such as sociolinguistics and psycholinguistics, which represent the two main perspectives from which the issue can be approached, the societal and the individual level. While both angles have contributed to the analysis of CS, they also involve problems, as Gardner-Chloros (1991) explained, due to its multidimensional character. Part of the complexity of the study of language switching emerges from the different connotations and social meanings it carries as well as from the fuzzy edges of the phenomenon, such as the borderline between CS and borrowing (Lipski, 2005; Myers-Scotton, 1992).

Two main types of CS are generally distinguished in the literature: intersentential $C S$, which involves "switches from one language to the other between sentences", and intrasentential $C S$, which occurs "within the same sentence, from single-morpheme to clause level" (Myers-Scotton, 1992: 4). Appel and Muysken (1987) distinguished a third type of CS which involves an exclamation, a tag or a parenthetical which is expressed in a language other than the language used in the rest of the sentence. Because these tag-switches serve as an emblem of the bilingual character of an otherwise monolingual sentence, Poplack (1980) uses the term emblematic switching for this type of CS. Although these are the primary switches, Thompson and Lamboy (2012: 53) mention a fourth category at the conversation or discourse level. This fourth type is actually included in the intersentential switches and is influenced by the stylistic features sought after.

Another traditional classification is the one proposed by Lipski (1982: 195), who distinguishes three types of CS: Type I involves the simple insertion of words; while Types II and III respectively coincide with cases of intersentential and intrasentential CS. ${ }^{4}$ Type II occurs in texts which are "produced in a single language, with switches occurring at phrase/sentence boundaries". As Lipski (1982: 195) explains, "[i]t is impossible, for such texts, to establish the true bilingual competence of the writer, but the fact that entire propositions are expressed monolingually indicates that the writer sees fit to separate the two linguistic and cultural domains." In contrast, Type III, which is described by Lipski (1982: 195) as the kind of switch that provides "the richest and most rewarding terrain for literary analysis", really shows "the degree of integration in the writer's bilingual grammars". It involves intrasentential code switches, i.e. the switches occur within the sentence or clause, which requires a much higher level of bilingualism and "presupposes a balanced bilingual grammar" (Montes-Alcalá, 2016: 
198) to facilitate a smooth combination of the two systems. This explains why in many studies on literary CS this tends to be the least frequent type (Flores Ohlson, 2008; Montes-Alcalá, 2005a, 2015b; Söderqvist, 2009).

CS has generated "a great deal of pointed discussion in the public domain" (Bullock and Toribio, 2009) but also in the scholarly world, mainly because of its many linguistic, social and cognitive implications, which are in line with "the different implications of switching from a dialect to a standard language and switching registers" (Gardner-Chloros, 1991: 57). As Zentella (1997: 80) put it, “[w]hereas monolinguals adjust by switching phonological, grammatical, and discourse features within one linguistic code, bilinguals alternate between the languages in their linguistic repertoire as well."

Since CS is felt to be more of a construct, researchers "may reasonably differ as to its definition and scope" (Gardner-Chloros, 1991: 186). It has actually been widely studied from different perspectives by an array of scholars who have shown that bilinguals tend to codeswitch for a variety of social and discursive factors (cf. Poplack, 1980; Lipski 1982, 2005; Appel and Muysken, 1987; Heller, 1988, 1992; GardnerChloros, 1991; Eastman, 1992; Myers-Scotton, 1993; Milroy and Muysken, 1995; Tabouret-Keller, 1997; Zentella, 1997; Auer, 1998; Jacobson, 1998, 2001; Poplack and Meechan, 1998; Moyer, 1998; Montes-Alcalá, 2000a, 2000b, 2001, 2005a; 2005b; Callahan, 2004). As Gardner-Chloros (2015) put it, "Code-switching is infinitely more than just throwing in a word from your other language. It can serve to bring emphasis, define the speaker's identity, be conspiratory or even be used to exercise powers and is usually an attempt to have an effect on the listener". In addition, CS seems to be governed by "a complicated and as yet not fully delimited set of constraints" (Lipski, 1982: 191). Most studies on CS have underlined its complexity and "its endless psychological and sociological ramifications" (Gardner-Chloros, 1991: 68).

The difficulties to characterize CS definitively are due to the broad range of contact phenomena it comprises, which Bullock and Toribio (2009: 2) summarize as follows:

First, its linguistic manifestations may extend from the insertion of single words to the alternation of languages for larger segments of discourse. Second, it is produced by bilinguals of differing degrees of proficiency who reside in various types of language contact settings, and as a consequence their CS patterns may not be uniform. Finally, it may be deployed for a number of reasons: filling linguistic gaps, expressing ethnic identity, and achieving particular discursive aims, among others. Given these factors, it is not surprising that there exists debate in the literature concerning the precise characterization of $\mathrm{CS}$ and how various kinds of language contact varieties are to be classified.

Interestingly, scholars like Giles and Smith (1979) consider CS as part of a linguistic accommodation process which allows speakers to 'converge' or 'diverge' from their interlocutors. Following this line of thought, Jackson (2014: 142) claims that "language may be used as an identity marker to either draw us closer to or further apart from individuals with a different linguistic and cultural background", while others, like Tabouret-Keller (1997: 147), conceive it as a way to reinforce the sense of a shared, 
mixed identity and to maintain the status quo of the bilingual situation. This is nothing but evident, as long as CS "can reflect dual identity" (Clyne 2003: 214); in fact, as Lipski (1982: 196) put it, for many bilinguals in the USA, "the dynamic switch to Spanish is fundamentally an identity marker in speakers whose linguistic abilities would allow them to express themselves equally well in English." Similarly, Myers-Scotton (1993) discussed the socio-psychological aspect of CS and argued that it can be used to convey intentional meanings of a socio-pragmatic nature. In her view, this sociopsychological significance of switching either languages or linguistic varieties seems to reveal "that the speaker has the multiple identities associated with each of the linguistic varieties involved" (1993: 7). This goes in line with Heller's (1988: 270-1) assertion that "CS is a strategy which can signal shared culture or be used to create it." More recently, Pennycook (2012) conceptualizes CS as functioning as an index of affective experiences, while Bonnin (2014) understands it as an alternation between symbolic representations of language.

Several researchers have also described the many important functions served by CS, which will be commented on below. As Gardner-Chloros (1991: 190) explains, it seems obvious that speakers' motivations for CS are often complex and tend to be made up of several layers which researchers try to disentangle. However, it is also noteworthy that for some bilinguals CS "merely represents another way of speaking" in such a way that often they codeswitch "simply because they can and oftentimes may not be aware that they have done so" (Bullock and Toribio, 2009: 11). Alternatively, in the literature on CS mention is made of cases in which the bilingual speaker may just opt for the language with the shortest or simplest word, the choice being also sometimes due to linguistic ability, vocabulary accessibility or even to occasional memory lapses (Bonvillain, 2008: 321).

On the other hand, it is interesting to note that most of the research dealing with CS has focused on the oral production of bilinguals (Grosjean, 1982; Auer, 1984; Zentella, 1997; Moyer, 1998; Heredia and Altarriba, 2001; Anderson and Toribio, 2007; Lipski, 2014, among others). It is only relatively recently that some scholars have shown an interest in analyzing written CS (Sebba, 2000; Callahan, 2004; Montes-Alcalá, 2005a, 2005b, 2012, 2015; Sebba, Mahootian and Jonsson, 2012; Müller, 2015) or even contrasting the two modes, speech and writing (Lipski, 1982; Montes-Alcalá, 2000a, 2000b, 2001). Thus, Callahan (2004) proves that written CS follows for the most part the same syntactic patterns as its spoken counterpart. She offers an overview of written CS research, and concurs with other scholars (Keller, 1984; Kanellos, 2003) that CS is used by writers to achieve their aims.

Likewise, Sebba, Mahootian and Jonsson (2012) have approached CS in writing as rhetorical practices of contact zones. They illustrate how language mixing in written discourse has occurred historically and how this phenomenon continues in our contemporary time, when interest in this particular subject has increased noticeably. This is also evidenced by the appearance of a special issue of the academic journal Language and Literature (2015, vol. 24.3) specifically devoted to CS in literature. This volume has answered the long felt need of more critical work on CS in written 
discourse which, in contrast to its oral counterpart, had not developed such a considerable amount of literature. It is only in the last decades that scholars have started filling the gap, with the analysis of written CS in a variety of genres. Our aim is to modestly contribute to the field with this piece of research that explores the dynamics of CS in a sample of popular romance fiction novels set in the Canaries.

\section{Corpus description, hypothesis and methodology}

As stated above, the romances that will be examined here were taken from the corpus that is being compiled for Research Project FFI2014-53962-P. This interdisciplinary project emerges from previous research on the Anglo-Canarian sociocultural, linguistic and literary relationships, particularly from González-Cruz's (1995, 2002, 2011a, 2011b, 2013, 2014) studies on the wide English bibliography on the Canaries. Popular romance fiction novels were not included in those bibliographical repertoires and have only recently begun to be taken into consideration (González-Cruz, 2015). All the texts in the corpus were published by Harlequin and Mills and Boon female English-writing authors and follow the typical pattern of this denigrated subgenre, i.e., they all tell stories that are centred on love and the couple and conclude with "an emotionallysatisfying and optimistic ending" (cf. Romance Writers of America). The novels share one crucial feature: they include a trip and a stay in one or more of the Atlantic islands, which are typically described as a paradise with very different sociocultural traditions. Interestingly, both the narrator and the characters are aware of the sociocultural and linguistic differences and tend to make reference to them. This provides an interesting framework and material to carry out a variety of analyses related to a number of challenging issues, including identity and otherness, gender, paradise discourse, as well as intercultural and even linguistic contact, since the texts tend to be interspersed with Spanish (and Portuguese) terms and expressions. These words and phrases perform different communicative functions and reach a wide international readership who can't but become familiar with them. In turn, this may contribute to their eventual incorporation into the lexical repertoires of the English language, as argued by González-Cruz (2011b; 2017).

For the present study, I selected a total of 16 romances (cf. References) which, just like the rest of the works in the Project corpus, are all set, wholly or partially, in the Canaries. The texts have been divided into two samples on the grounds of their protagonists' origins. Thus, the first one (which we will call sample A) includes a total of 8 novels whose protagonists make up a mixed couple, namely a Hispanic (Canarian) hero and an English-speaking heroine who visits or settles on the island temporarily. The second sample (sample B) also consists of a total of 8 novels but their protagonists are both of British origin with no family or close social bonds in the Canaries. Since by definition CS and borrowing tend to occur in bilingual situations, such as the ones portrayed in these texts, we expected the romances in sample A to include a higher number of Hispanicisms than those in sample B, whose protagonists are both British citizens visiting the islands either as mere tourists or for business. With this hypothesis 
in mind, we carried out our study of the presence and the form and functions of the Hispanicisms in the novels.

As for the methodology, it consisted in carefully reading the selected texts in order to manually log all the occurrences of Hispanicisms, used either by the narrator or by the characters. As stated, two main perspectives were adopted for the description and analysis of these Hispanicims, namely their forms and the functions they seem to play in the written discourse in English. For the former, we rely on the distinction between lexical and syntactic CS, depending on whether they respectively involve single words, or phrases and sentences. In this type of analysis Lipski's (1982) well-known typology for CS was employed.

In the analysis of the functions performed by the Hispanicisms in the text, we will also focus on the potential that they seem to have as a means of pragmatic marking of the English discourse of the novels by creating associations and meaning extensions (Khoutyz, 2009), since we are totally aware of "the symbolic significance of language choice" (Clyne, 2003: 42). In this respect, we rely also on Culpeper's (2014) claim that "the words of a text create a particular impression of a character in the reader's mind". This socio-pragmatic viewpoint will be highlighted in the analysis of the cases of CS in our samples.

\section{Results and discussion}

The results of both the formal and the functional analyses of the Hispanicisms in the two samples will be presented separately here. Thus, in sub-section 4.1 we will study the data obtained from the perspective of their form, following Lipski's (1982) typology. Then, in 4.2 we will focus on the functions that the Hispanicisms collected seem to perform in the English texts. For this purpose, we resorted to the typologies offered by several authors as a guide to design our own classification.

\subsection{Lexical vs. syntactic CS: Lipski’s (1982) typology}

$A$ total of 264 different Hispanicisms were found in the 16 romances studied, including words, phrases and sentences. Neither toponyms nor the many occurrences of the same Hispanicism were considered for the count. Tables 1 and 2 below provide the data obtained, classified by sample. When comparing the figures in both tables, we can notice that there is a tendency for the works in sample A to include a higher number of Hispanicisms than those in sample B, except for two romances in the latter, those by Airlie (1958) and Danbury (1973) in which a considerable number of Spanish words are also employed. Having read all the novels, we are in a position to try to give an explanation for these exceptional cases: in Airlie's (1958) and Danbury's (1973) texts, even though the male protagonists are native English speakers, they have been long established in the Canaries, where they have close social bonds, thus becoming relatively Spanishized or Canarianized. In addition, the plots in these two novels develop mainly in the islands, while in the rest of the romances in this sample, part of 
the action takes place in other locations, both in Britain and in continental Spain. These factors may explain the contrast between the considerable number of Spanish words inserted in these two novels (and in the ones in sample A) and the relatively few Hispanicisms included in the other works in sample B.

As expected, this seems to indicate that the fact that the protagonists form a mixed couple (invariably a Spanish hero and an English-speaking heroine) implies a greater involvement with the Hispanic context, which in turn determines the occurrence of more Hispanicisms in the texts. This can be interpreted as a literary strategy used by the authors in order to represent the characters' bilingual interactions and to recreate more vividly the bilingual context in which the plots are developed.

As shown in Tables 1 and 2 below, the majority of the Hispanicisms collected were cases of lexical CS. The figures also prove that switches involving phrases were more frequent than those which meant the insertion of sentences.

\begin{tabular}{|l|l|l|l|}
\hline Authors & $\begin{array}{l}\text { Insertion of } \\
\text { different } \\
\text { Spanish words }\end{array}$ & $\begin{array}{l}\text { Insertion of } \\
\text { different Spanish } \\
\text { phrases }\end{array}$ & $\begin{array}{l}\text { Insertion of } \\
\text { different } \\
\text { Spanish } \\
\text { sentences }\end{array}$ \\
\hline Arbor (1967) & 47 & 15 & 0 \\
\hline Britt (1977) & 24 & 8 & 0 \\
\hline Corrie (1980) & 20 & 4 & 1 \\
\hline Lane (1978) & 33 & 7 & 4 \\
\hline Mayo (1988) & 20 & 3 & 1 \\
\hline Mayo (1994) & 31 & 8 & 5 \\
\hline MacLeod (1982) & 48 & 7 & 3 \\
\hline Thorpe (1973) & 38 & 10 & 1 \\
\hline
\end{tabular}

Table 1: Total number ${ }^{5}$ of Spanish words, phrases and sentences found in sample A (mixed couples).

\begin{tabular}{|l|l|l|l|}
\hline Authors & $\begin{array}{l}\text { Insertion of } \\
\text { different } \\
\text { Spanish words }\end{array}$ & $\begin{array}{l}\text { Insertion of } \\
\text { different Spanish } \\
\text { phrases }\end{array}$ & $\begin{array}{l}\text { Insertion of } \\
\text { different } \\
\text { Spanish } \\
\text { sentences }\end{array}$ \\
\hline Airlie (1958) & 38 & 1 & 1 \\
\hline Danbury (1973) & 29 & 12 & 0 \\
\hline Field (2004) & 3 & 0 & 0 \\
\hline Jameson (1987) & 6 & 0 & 0 \\
\hline Mayo (1990) & 3 & 0 & 0 \\
\hline Mayo (1992) & 5 & 2 & 1 \\
\hline Olfield (1986) & 12 & 1 & 0 \\
\hline Peake (1983) & 3 & 0 & 0 \\
\hline
\end{tabular}

Table 2: Total number of Spanish words, phrases and sentences found in sample B (British couples) 
Following Lipski's widely-accepted classification for written CS, we must say that many of the romances compiled for the Project belong to Type I only, i.e., they can be described as monolingual texts "with a handful of L2 words thrown in for flavor" (Lipski, 1982: 195). However, in the two selected samples (particularly in sample A) a considerable number of cases of both Type I and Type II have been found, the former being more numerous than the latter, as suggested in Tables 1 and 2 above. However, no real cases of Type III could be identified.

Below we offer examples ${ }^{6}$ of the two types of CS that were used in the texts. As stated above, Type I, merely involves "the insertion of individual items for a variety of reasons and effects", as illustrated in the following utterances:

(1) I still do, querida. (Lane, 1978: 185)

(2) They found rooms in a pension, and Rhiannon was too tired... (Mayo, 1988: 201)

(3) Lucía came out to the patio to join them. (MacLeod, 1982: 151)

(4) Señora Perestello had only just emerged from her own siesta. (Thorpe, 1973: 123)

(5) They had a simple meal of paella, cheese, local wine and coffee. (Lane, 1978: 56)

(6) 'But you remember his novia?' (Thorpe, 1973: 123)

(7) 'She came to return your mantilla, which I'd left at the bungalow.' (MacLeod, 1982: 158)

(8) 'I'm very much looking forward to the fiesta'. (Thorpe, 1973: 89)

(9) ... the sound of voices from the salón below... (MacLeod, 1982: 156)

(10) ... full of women chattering over their merienda. (MacLeod, 1982: 26)

(11) ... a choice of mariscos, pulpitos, gambas and many fishes. (Oldfield, 1986: 61)

(12) There is a supermercado only (Jameson, 1987: 73)

(13) ... I will go and have a word with the policia, even though... (Mayo, 1992: 24)

(14) ... encouraged to be macho by indulgent parents. (MacLeod, 1982: 63)

In turn, Type II typically involves switches that occur at the phrase or sentence level, offering "two complete sets of logical propositions". According to Lipski (1982: 195), it usually "entails a shift of total domain of discourse", although this does not always seem to be the case in the following examples taken from our samples:

(15) '...but I see your-er-your hermana. Comprende usted?' (Mayo, 1992: 118)

(16) ...her dark eyes aglow. 'Te quiero mucho, Phillip!' she sighed... (Airlie, 1958: 49)

(17) ... she heard Manolo’s excited voice. 'Papá, Papá, donde estás?' (Mayo, 1994: $152)$

(18) 'Yo comprendo! It is a good thing, is it not, to laugh together and be happy?' (MacLeod, 1982: 111) 
(19) 'Te quiero'. This time she was the one to murmur those wonderful Spanish words (Lane, 1978: 185)

(20) 'Perdóneme, I thought I was doing you a favour. If you don't want to enjoy the carnaval, then so be it. Es tuya la perdida, no mia'. (Mayo, 1994: 70)

(21) 'If you wish, but it will be of no consequence either way. Buenas noches, Cathy. Lo siento mucho!' (MacLeod, 1982: 113)

(22) 'Tanya, this is my son, Manolo. Manolo, esta es la señora de quien te hablé.' The boy frowned. 'No comprendo, Papá.' (Mayo, 1994: 87)

(23) 'Buenas noches everyone! Velocidad moderada, Ramón!' (MacLeod, 1982: 134)

(24) 'Tomorrow the fiesta. Adiós, chica!' (Thorpe, 1973: 87)

\subsection{The sociopragmatic functions of CS}

Here we will focus on the variety of linguistic and interactional functions that CS can perform. These are seen as functions of a socio-pragmatic nature, as they have to do with the speaker's (or writer's) communicative intention, that is, whatever the speaker/writer wants to express through CS and the social functions CS can play, as well as with how CS affects the hearer's (or reader's) interpretation. Before offering our findings, we will make reference to some previous research into this issue, which proved to be helpful for the classification of our data.

\subsubsection{Previous studies}

There is no single classification or a specific number of functions established for CS. Actually, an array of scholars have listed several stylistic or sociopragmatic functions it can perform, usually to suit the findings of their studies. This is nothing but natural since, as Clyne (2003: 241) put it, following Muysken (2000),

A researcher's data, experience and interests exercise an influence on the models they develop. With the great expansion of research in this field, language contact studies are served by a multiplicity of models each of which captures part of the picture and contributes to the totality.

Thus, Valdés-Fallis (1976) refers to parenthetical uses, emphasis, exclamations, repetitions, symmetric alternation, linguistic routines, and anticipation. Other internal factors that Valdés-Fallis points out are random frequent lexical items, lexical need, triggers, stylistic changes, and discourse markers. In turn, Poplack (1980) talks about interjections, idiomatic expressions, tags, and quotes. On the other hand, Gumperz (1992) listed six functions: quotes, listener specification, interjections, reiterations, message qualification, and personalization as opposed to objectivization. Interestingly, Bonvillain, (2008: 321-26) states that, as a bilingual conversational strategy, CS has numerous discourse and interactional functions which she categorizes (cf. Table 3). More recently, Callahan (2004), Jonsson (2010) and Montes-Alcalá (2016) have proved 
that literary CS is used for a variety of socio-pragmatic and stylistic purposes similar to those found in bilingual speech. All of them propose a number of categories to suit their data; in particular, Montes-Alcalá (2016), following previous classifications, specifically tried to group related functions under the same category, both for clarity and economy's sake. Table 3 below summarizes the different taxonomies employed by some of these authors, whose categories have partially guided our analysis.

\begin{tabular}{|c|c|c|c|c|}
\hline Gumperz (1982) & $\begin{array}{l}\text { Bonvillain } \\
\text { (2008) }\end{array}$ & $\begin{array}{l}\text { Callahan } \\
\text { (2004) }\end{array}$ & $\begin{array}{l}\text { Jonsson } \\
(2010)\end{array}$ & $\begin{array}{l}\text { Montes } \\
\text { Alcalá (2016) }\end{array}$ \\
\hline quotes & quotes & quotations & quotations & quotations \\
\hline $\begin{array}{l}\text { listener } \\
\text { specification }\end{array}$ & $\begin{array}{l}\text { marking } \\
\text { discourse } \\
\text { boundaries }\end{array}$ & vocatives & gaps & $\begin{array}{l}\text { clarification } \\
\text { /elaboration }\end{array}$ \\
\hline interjections & $\begin{array}{l}\text { to segment } \\
\text { phrases } \\
\text { marking } \\
\text { qualification, } \\
\text { explanation or } \\
\text { elaboration } \\
\end{array}$ & expletives & interjection & $\begin{array}{l}\text { lexical or } \\
\text { cultural need }\end{array}$ \\
\hline reiterations & tag questions & referential & reiteration & emphasis \\
\hline $\begin{array}{l}\text { message } \\
\text { qualification }\end{array}$ & attention getter & $\begin{array}{l}\text { commentary } \\
\& \text { repetition }\end{array}$ & $\begin{array}{l}\text { word / } \\
\text { language play }\end{array}$ & stylistic \\
\hline \multirow[t]{7}{*}{$\begin{array}{l}\text { personalization } \\
\text { vs. } \\
\text { objectivization }\end{array}$} & routine phrases & $\begin{array}{l}\text { set phrases, } \\
\text { tags \& } \\
\text { exclamations }\end{array}$ & & \\
\hline & $\begin{array}{l}\text { ease of } \\
\text { vocabulary / } \\
\text { simpler } \\
\text { expression } \\
\end{array}$ & $\begin{array}{l}\text { discourse } \\
\text { markers }\end{array}$ & & \\
\hline & $\begin{array}{l}\text { to signal } \\
\text { changes in } \\
\text { syntactic } \\
\text { constructions }\end{array}$ & directives & & \\
\hline & $\begin{array}{l}\text { repetition as an } \\
\text { emphatic } \\
\text { device }\end{array}$ & & & \\
\hline & $\begin{array}{l}\text { marking } \\
\text { politeness \& } \\
\text { solidarity }\end{array}$ & & & \\
\hline & $\begin{array}{l}\text { shifts within } \\
\text { discourse } \\
\text { (focus, } \\
\text { addressee, } \\
\text { topic) }\end{array}$ & & & \\
\hline & $\begin{array}{l}\text { interactional \& } \\
\text { emotional } \\
\text { purpose }\end{array}$ & & & \\
\hline
\end{tabular}

Table 3: Classification of the socio-pragmatic functions of CS by several authors 
In the following sub-section we will offer our own classification, illustrating the different types of functions that were identified in the samples. Although occasionally there may be some overlapping, the data have been organized according to the most prominent or primary function they seem to perform, taking into account the difficulties that have also been encountered by other researchers in this kind of task. For instance, Montes-Alcalá (2016: 200) warns that "not each and every language switch will always fulfill a unique or specific function", while Zentella (1997: 99) admits that "no complete accounting may ever be possible", in the same way as "imputing the reason for a monolingual's choice of one synonym over another" is almost impracticable.

\subsubsection{Functions of $C S$ in the samples}

The following seven functions were identified in the selected novels. I will describe each of them briefly and then a few examples will be provided.

\section{i) Vocative function}

This is a relatively frequent function that tends to occur whenever Hispanicisms are used by the characters as attention getters, nicknames, address terms or as terms of endearment. In most of the texts studied here Spanish address terms abound, with or without a proper noun, for instance Don Phillip, Señor don Julio, señor, señora, señorita, señorito, Marqués, Marquesa, Madre, Padre, Papa, Abuela, Abuelo, pequeña prima, pequeña hermana, chica, amigo, etc. The following are some examples:

(25) 'This way, Senorita!' (Airlie, 1958: 29)

(26) 'In here, senorito' he said. (MacLeod, 1982: 90)

(27) 'If you know, amigo,' she asked gently'. (Airlie, 1958: 53)

(28) 'You are quite safe with me, chica' (Thorpe, 1973: 11)

Similarly, several terms of endearment, such as amor mio, mi corazón, amada, amada mía, chica mía, querida, mi niña, have also been found frequently performing this vocative function, as in the utterances below:

(29) 'You have made it very plain, mi niña, that you want nothing more to do with me.' (Mayo, 1994: 56).

(30) 'There's nothing to fear in love, amada' (Thorpe, 1973: 112)

(31) '... you must remind me, querida.' (Airlie, 1958: 65)

(32) 'You are improving, chica mía!' (Thorpe, 1973: 96)

(33) 'Mi corazón, I would never do that.' (Mayo, 1994: 169).

(34) 'You are very sweet, chiquita', he said softly. (MacLeod, 1982: 111)

ii) Routine formulas 
This discourse function is typically performed by expressions of a sociolinguistic nature, that is, they are related to certain social situations in which they tend to be used recurrently. In fact, the appearance of these routine formulas in discourse involves significant social meaning (Coulmas, 2005: 239). Kecskes (2010) defines them as prefabricated lexical units which are crucial for linguistic fluency. In our sample, they consist mainly of expressions such as Buenos dias, buenas tardes, buenas noches, muchas gracias, etc. which occur quite frequently in the texts studied. Specific examples follow:

(35) 'Buenas tardes, señorita. The Señor Marqués awaits you in the salon.' (Britt, 1977: 9)

(36) 'Buenas noches, madrastra!' (MacLeod, 1982: 58)

(37) 'Buenos días, señora,' [...]. 'Cómo está?' (Lane, 1978: 19)

(38) 'Sí, Señor Martel' (Corrie, 1988: 145)

(39) 'Muchas gracias, ' (MacLeod, 1982: 101)

iii) Set phrases

This function is quite similar to the previous one. These set phrases or idiomatic expressions are often inserted in the dialogues. The following are some examples:

(40) 'Hasta la vista!' (MacLeod, 1982: 45)

(41) 'Viva España!' (Lane, 1978: 103)

(42) 'Te quiero mucho' (Airlie, 1958: 50)

(43) 'Adelante!' (MacLeod, 1982: 115).

(44) 'Comprende usted?’ (Mayo, 1992: 118)

(45) 'Salud!' (Mayo, 1992: 82)

(46) 'Bienvenida señorita!' (MacLeod, 1982: 49)

iv) Quotes

This is one of the functions that is most frequently performed by the Hispanicisms in the analysed samples; interestingly, all the authors in Table 3 have included it in their classifications. It typically occurs in the texts whenever the narrator opts for directly quoting the exact words uttered by any character, rather than reporting his/her speech:

(47) The child murmured 'Buenos dias.'(Danbury, 1973: 23)

(48) Catherine heard Manuel say 'Sí, señor'. (MacLeod, 1982: 100)

(49) 'Si', the boy nodded. (Mayo, 1992: 118)

(50) 'Gracias, Cathy!' he said. (MacLeod, 1982: 167)

(51) ....as he came over with a jovial 'Hola' for his uncle... (Arbor, 1967: 89)

(52) Alberto [...] greeted Lucie with a 'Buenos dias' (Danbury, 1973: 67) 
(53) 'Buenas noches, señorita!' she added with a small, mocking laugh. '(MacLeod, 1982: 113)

Notice how the Hispanicisms in utterances (48) and (50) above, 'Sí, señor,' and 'Gracias,' obviously perform the function of quoting, but at the same time they may also be categorized as routine formulas. Thus, they are instances of the abovementioned cases of overlapping.

\section{v) Interjections}

Interjections are defined as words or phrases that are used to express a strong feeling such as surprise, pain or horror and which are often said loudly and emphatically. With their emphasis on emotions and feelings, interjections are also related to Jakobson's well-known expressive or emotive function, which none of the authors selected in Table 3 mentions. Only Bonvillain (2008) talks about a function that has to do with interactional and emotional purposes, while Callahan (2004) categorizes expletives as another type of function. In the following example the interjection used might also be classified as an expletive:

(54) 'Maldito sea, Tanya, how can you do this to me?' (Mayo, 1994: 138)

Other cases of Hispanicisms which can be included in this category of interjections because of the emotional sense they involve, are shown below. Notice that (56) can also be a quote:

(55) 'Dios, woman, I would be better the only one' (Thorpe, 1973: 181)

(56) ....she gave a sudden exclamation. 'Oh dolor!' (Dansbury, 1973: 92)

vi) Repetition or reiteration

This category is employed by almost all the authors in Table 3 above. Apparently, the only exception is Montes-Alcalá (2016), who seems to include this phenomenon in what she calls emphasis. In fact, this function occurs when a speaker or character repeats in Spanish what he or she has previously mentioned in English (or viceversa), probably with the aim of explaining the meaning of the Hispanicism or in order to reiterate the message for emphasis. The following examples have been taken from the samples analyzed here:

(57) 'And so bonito, so handsome' (Jameson, 1987: 74)

(58) 'Bueno-bueno, good-good.' (Lane, 1978: 53)

(59) 'Beatriz is my cuñada, my sister-in-law' (Mayo, 1994: 60)

(60) 'Nothing, nada', she repeated in Spanish". (Jameson, 1987: 168) 
(61) 'Enamorada, sweetheart, something is wrong?' (Mayo, 1994: 111)

(62) 'Te quiero. I love you, and I'll marry you!' (Lane 1978: 175)

Interestingly, in utterance (61) the Hispanicism enamorada sounds rather artificial; in my opinion, it would have been more natural to use another endearment, such as cariño, for instance. Again, this is another case of overlapping as, in addition to the function of repetition or reiteration, this Hispanicism performs the vocative function as well.

(vii) Referential function

It is common knowledge that this is the central function of language. In fact, it is a sort of prerequisite for the rest of functions, as pointed out by Brown (1958: 7), who proves that every single word in a language is right there for some reason and for some purpose, i.e., every word has a referent. This is in line with Page's (1988: 1) idea that "every work of literature possesses in every word that composes it a selective and purposive nature". When assigning this referential function to some cases of CS in her corpus, Callahan (2004: 70-71) noted:

Whether codeswitched material can have a purely referential function is open to interpretation. For example, several of the texts contain Caló vocabulary. It could be argued that the words jaina 'woman, girlfriend' and bato 'man' communicate certain nuances that their equivalents in standard Spanish would not. However, no terms are entirely neutral; the choice of words from the standard over a regional variety or vice versa communicates still other nuances. But this does not detract from their main function in the discourse: the transmission of information in a narrative.

This referential function can be identified whenever the narrator or any character resorts to a Spanish word to make reference to a particular object or entity. Here a distinction has to be made between those cases in which the choice seems to be justified by a lexical or cultural need, as there is not an exact equivalent in the English language to refer to that object or entity, and those cases in which the writers could have used an English word but opted for the Hispanicism. The former situations are easily explained, as Romaine (1989: 55) states, since "when moving to a new setting, speakers will encounter a variety of things which are specific to the new environment or culture and will adopt readily available words from the local language to describe them." According to Weinreich (1979: 57), the reason for this is merely that "using ready-made designations is more economical than describing things afresh". This lexical or cultural need is simply unavoidable, as the following examples taken from our romances illustrate: 
(63) 'Look, this is a shop where they sell those timples', he pointed out. (Danbury, 1973: 115)

(64) 'Julio has Guanche blood.' (Airlie, 1958: 30)

(65) ....water dripping from his poncho,... (MacLeod, 1982: 175)

(66) 'What shall I play for you, senoritas? A fandango or a gay sardana?' (MacLeod, 1982: 82)

(67) ...Pasqual cooked cabrilla he had caught early that morning (Mayo, 1988: 40)

(68) Zander explained that this jameo was the most famous. (Peake, 1983: 71)

(69) '... a Canary speciality called caldo de pescado, made with a local fish and very tasty...'(Danbury, 1973: 135).

(70) '... where they dance flamenco in the true way'. (MacLeod, 1982: 95)

(71) ....and she thoroughly enjoyed Rancho Canario - a rich vegetable soup... (Mayo, 1988: 116)

(72) ... to earn a few pesetas for their daily bread. (Airlie, 1958: 138)

(73) ... and balls of gofio dipped in a fiery sauce called mojo. (Field, 2004: 129)

Very often these switches into Spanish occur only with the insertion of words or phrases which are not followed or preceded by any translation or explanation of their meaning. However, on other occasions the authors immediately provide an English synonym or some kind of clarification of their meaning, as in the sentences below:

(74) 'You've eaten many kinds of turrón - this almond sweet...' (Danbury, 1973: $135)$

(75) ...the opening parade, the comparsas show, the dancers, the fancy dress contest, the songs of the rondallas- street musicians - the murgas - groups of musical critics... (Mayo, 1994:142)

(76) ... he veered across a bridge over a barranco - a dried up river course (Lane, 1978: 153)

(77) They're, I'm told, called malpais, that is, modern lava zone. (Peake, 1983: 71)

(78) 'Bacalao', confirmed Charlene with a smile, 'or codfish to you and me, and these - indicating the potatoes, - are papas arrugadas, which, translated literally, means wrinkled potatoes...' (Mayo, 1994: 5)

(79) 'Sí, comprendo! I understand', Trudy said quickly. (Lane, 1978: 172)

(80) This is a special island kind with the cornmeal, gofio.(Danbury, 1973: 115)

(81) Tapas, Dervan called them, these tasty bits of food. (Mayo, 1990:41)

(82) ... when she heard the silbo, the unique whistling language native to the island (Mayo, 1988: 199)

(83) ... not far from the cable-car station was a parador, a government-owned hotel ... (Lane, 1978: 56)

(84) 'You will not yet have met Madre - my mother.' (Thorpe, 1973: 26)

(85) Zafra - that is the tomato season-is from late October to the end of April. (Mayo, 1994:102). 
Occasionally, explaining the authors' preference for a switch into Spanish might seem relatively easy, as in the following sentences:

(86) 'I have ordered entremeses because I thought that Felicity would not care for soup on such a warm evening,' Sisi informed Philip. (Airlie, 1958: 39)

(87) 'I will get my son and take him to see the eleccion de la reina infantil...' (Mayo, 1994:77)

In (86) the author uses the Hispanicism entremeses, for which there is not a really English equivalent. The word that is generally used in that language to express the required meaning ('different dishes of cold food that have been especially prepared to be eaten before the main course of a meal') originally comes from French, namely, hors d'oeuvres.

In turn, although the expression elección de la reina infantil in (87) might have relatively easily been translated into "the children's carnival queen contest", the author opted for the Hispanicism as it obviously refers to an event which is essentially alien to the Anglosaxon culture.

In contrast, in the sentences below it is not a simple task to explain the reasons why the authors preferred to employ the Spanish terms, instead of their English equivalents, since there is no apparent lexical or cultural need for them:

(88) 'My mother was good and sweet and delicada.' (MacLeod, 1982: 93)

(89) Round the corner strode a policia ... (Lane, 1978: 43)

(90) 'I need a siesta' Shaine moaned. (Field, 2004: 129)

(91) 'We are invited to the fiesta,' she announced. (Airlie, 1958: 69)

(92) 'I will show you the hacienda at its best.' (MacLeod, 1982: 52)

(93) She had drunk too much of Crisógono's vino. (Mayo, 1994: 109)

(94) '... Then I parked her with a large limonada, gave Manuel back his red badge of courage...' (Arbor, 1967: 66)

(95) 'I have noticed this tristeza in you...' (Britt, 1977: 54)

(96) ...the grey ribbons of the autopista with heat shimmering from the surfaces (Lane, 1978: 21)

(97) '...on the shaded end of the patio outside the salon windows...' (MacLeod, 1982: 66)

(98) ... as he picked up the manta he had discarded on one of the sofas... (Airlie, 1958: 39)

(99) 'What do you think of my handsome sobrino?' (Mayo, 1994: 84)

(100) 'She is her true nieta, full of spirit... (MacLeod, 1982: 62)

(101) '... if your stepmother's clinic needs another medico'. (Lane, 1978: 73)

(102) ... a long, narrow barranco, leading to the sea... (Airlie, 1958: 71)

(103) 'Where do courting couples go? Along the playa. (Arbor, 1967: 67) 
It is interesting to note that a considerable number of the Hispanicisms above are registered in the Shorter Oxford English Dictionary on Historical Principles (2007, henceforth $S O E D H P$ ), that is, they have been officially incorporated as borrowings into the English lexical repertoire, which somehow 'legitimizes' their use. In fact, some seem to be relatively well-known by the English-speaking population (such as fiesta, flamenco, hacienda, macho, paella, patio, sangria, señorita, siesta, tapas, etc.), while others are not so widely spread, despite their being listed in that same dictionary. It is the case of barranco, bodega, cabaña, manta, meson, mirador, novio, playa, silbo, tristeza, vino, etc.

The point I want to make here is that many of the Spanish words which are used in the examples above, such as delicada, policia, vino, limonada, tristeza, autopista, patio, salón, manta, sobrino, nieta, medico, siesta, barranco and playa, might well have been replaced respectively by their English equivalents delicate, policeman, wine, lemonade, sadness, freeway, backyard, living-room, blanket, nephew, granddaughter, doctor, nap, ravine and beach. Admittedly, the concepts evoked by some Hispanicisms, such as fiesta, hacienda, siesta or patio may still add some Spanish flavour to their literal meaning, as long as they highlight some specific cultural features which their English equivalents are felt to lack. Following this line of thought, it could be argued that the idea of an English backyard, for example, does not coincide exactly with the image of a Canarian patio, which may justify the author's preference to employ this Spanish word that somehow echoes the conceptual and cultural difference in meaning. What seems obvious is that, without all these Hispanicisms, the texts would lose an important expressive effect: the sense of authenticity, realism and local color that they subtly provide with all their connotations, their codified pragmatic value and communicative potential, clearly adding some pragmatic value to the writing (Wotjak, 2006; Khoutyz, 2009; Jiménez Hurtado, 2001).

On the other hand, it has to be acknowledged that the use of Hispanicisms seems to be useful for the authors as a strategy that contributes to making readers aware of the sociolinguistic and sociocultural differences between the characters. It also helps them to construct their identities and to recreate the bilingual context in which the plots are developed. These specific functions cannot be denied and must be mentioned when it comes to describing and explaining the dynamics of the insertion of Hispanicisms in the English discourse of these novels.

\section{Conclusion}

In this paper I have explored the way Spanish words, phrases and sentences are used in two samples of works taken from a written corpus of English popular romances. The study has offered a two-fold analysis of the Hispanicisms inserted in the 16 novels selected, focusing both on their form and the socio-pragmatic functions they perform. With the examination of the dynamics of these cases of English/Spanish alternation in this doubly stigmatized subgenre, I hope to have contributed to the field of literary CS. 
As expected, we have found that in those texts whose protagonists form a mixed (English/Spanish) couple the authors tend to include a higher number of Hispanicisms. Specifically, the analysis of the way these Hispanicisms are incorporated into the English discourse shows the important role they play for the recreation of the bilingual context the novels portray, much more so when the protagonists belong to different cultures and speech communities, forming a mixed couple as is the case of the romances in sample A. In these texts, switches into Spanish seem to be more necessary and thus they tend to be much more frequent as a literary strategy employed by the authors in order to achieve the representation of the bilingual interaction between the lovers. The few exceptions to this rule, namely, Airlie's (1958) and Danbury's (1973) texts in sample B, have been explained on the grounds of the specifications and peculiarities of the heroes and the plots in these two novels, which reveal closer bonds and involvement with the islands.

On the other hand, we have shown that the majority of the Hispanicisms that the authors in the two samples tend to incorporate into their writings are single words (mainly nouns), which means that lexical CS (or Lipski's Type I) predominates. There are also cases of syntactic CS, which include both phrases and sentences, the former being much more numerous than the latter. These are all examples of Lipski's Type II, which involves inter-sentential CS, while no instances of Type III, or intra-sentential CS, have been found.

In line with the results of other studies, the data in this piece of research reveal that literary CS in these novels tends to perform a number of socio-pragmatic functions which are similar to the ones typically found in bilingual speech. The seven functions identified are the following: vocative function, routine formulas, set phrases, quotes, interjections, repetition or reiteration, and the referential function, with some cases of overlapping between them. Thus, I agree with Callaghan (2004: 2) when she states that "the successful application to a written corpus of a model developed for speech validates the use of written data, and shows that written codeswitching is not inauthentic". Likewise, as already observed, the Hispanicisms which occur in the selected texts oftentimes seem to fulfill some kind of pragmatic marking of their English discourse, by creating associations and meaning extensions. For this reason, I also concur with Montes-Alcalá (2016: 191), who emphasized "the social, pragmatic and cultural nature of CS over the search for grammatical constraints on the phenomenon."

Interestingly, a considerable number of the Hispanicisms employed in the texts studied are already recognized as borrowings as they have been registered in the SOEDHP (2007). Therefore, our claim here is that popular romance fiction novels can work as another channel for the spreading of Spanish words and expressions among their wide international readership, which, in turn, may eventually lead to their incorporation as borrowings into the English lexical repertoires. Further research will be needed to confirm this last point; however, we believe that this investigation has been useful to prove that these literary texts can not only successfully depict language contact 
situations, but they may also function themselves as instruments for language contact and borrowing. Thus, we concur with Braunmüller and House (2009:1-9) that:

for mutual influencing, immediate face-to-face social contact is actually not a necessary condition: lexical borrowing [...] can occur through book reading and learning by writers, teachers, students, who then pass on the new items to other people through other written texts.

\section{Notes}

1. Funding received from the Spanish Ministerio de Economia y Competitividad (MINECO) for Research Project FFI2014-53962-P, Discursos, género e identidad en un corpus de novela rosa inglesa ambientada en Canarias y otras islas atlánticas, is hereby gratefully acknowledged.

2. Following a general tendency in the literature, here we use the terms switching and mixing as synonyms. However, technically speaking, code-mixing refers to special cases of codeswitching which are so fast and dense that it is nearly impossible to ascertain which language is being spoken.

3. It is generally believed that Haugen coined the term but, according to Alvarez-Cáccamo (1998), the first scholar to use it was Hans Vogt, in an article published in 1954.

4. Type II is related to the so-called coordinate bilinguals (those who learned their two languages in different times or contexts) and the latter to the compound bilinguals (those who learned both languages at the same time or in the same context). Neither definition is completely satisfactory as most bilingual individuals show features of both types. However, it seems clear that the degree of bilingualism affects the type of CS.

5. Except for the sentences, many of the same Spanish words and phrases appear in several novels; therefore, the corresponding figures in their respective columns cannot be added up.

6. In all the examples given throughout the paper, the Hispanicisms are written in the original form in which they occur in the texts; as shown, sometimes they are neither marked with italics, nor spelt correctly.

\section{References}

\section{Primary Sources}

Sample A: mixed couples

Arbor, Jane. Golden Apple Island. Harlequin Books, 1967.

Baird, Jaqueline. At the Spaniard's Pleasure. Mills \& Boon, 2003.

Britt, Katrina. The Villa Faustino. Mills \& Boon, 1977.

Corrie, Jane. Island Fiesta. Mills \& Boon, 1980.

Lane, Pippa. Nurse in Tenerife. Mills \& Boon, 1978.

Mayo, Margaret. Savage Affair. Harlequin, 1988.

Mayo, Margaret. Bitter Memories. Mills \& Boon, 1994. 
McLeod, Jean S. Meeting in Madrid. Mills \& Boon, 1982.

Thorpe, Kay. An Apple in Eden. Mills \& Boon, 1973.

Wentworth, Sally. Dark Awakening. Mills \& Boon, 1984.

Sample B: British couples

Airlie, Catherine. Red Lotus. Mills \& Boon, 1958.

Danbury, Iris. The Silver Stallion. Mills \& Boon, 1973.

Field, Sandra. Surrender to Marriage. Mills \& Boon, 2004.

Jameson, Claudia. An Engagement is Announced. Mills \& Boon, 1987.

Mayo, Margaret. Mutual Attraction. Mills \& Boon, 1990.

Mayo, Margaret. Reluctant Hostage. Mills \& Boon, 1992.

Nickson, Hilda. Voyage of Discovery. Harlequin, 1987.

Oldfield, Elizabeth. Beware of Married Men. Mills \& Boon, 1986.

Peake, Lilian. Night of Possession. Mills \& Boon, 1983.

Wentworth, Sally. Fire Island. Mills \& Boon, 1989.

\section{References cited}

Alvarez-Cáccamo, Celso (1988): "From 'switching code' to 'code-switching'. Towards a reconceptualisation of communicative codes". In P. Auer, Code-switching in Conversation: Language, Interaction and Identity. London and New York: Routledge, 29-48.

Anchimbe, Eric A. and Richard W. Janne (2011): "Postcolonial pragmatics: An introduction". Journal of Pragmatics,43(6): 1451-1459.

Andersen, Gisle, Cristiano Furiassi, and Biljana Misic Ilic (2017): "The pragmatic turn in studies of linguistic borrowing". Journal of Pragmatics, 113: 71-76.

Anderson, Sheri L. (2004): Status and Solidarity through Codeswitching: Three Plays by Dolores Prida. MA Thesis. Texas A\&M University, College Station, hdl.handle.net/1969.1/536 Accessed 11 March 2017.

Anderson, Tyler K. and Almeida J. Toribio (2007): "Attitudes towards lexical borrowing and intra-sentential code-switching among Spanish-English bilinguals". Spanish in Context, 4(2): 217-240.

Appel, René and Pieter Muysken (1987): Language Contact and Bilingualism. London: Edward Arnold.

Auer, Peter (1984): Bilingual Conversation. Amsterdam: John Benjamins Publishing Company.

Auer, Peter (1988): Codeswitching in Conversation. Language, Interaction and Identity. London and New York: Routledge.

Bonnin, Juan Eduardo (2014):"Discurso político y cambio de código: la alternancia guaraní / español en el discurso de Fernando Lugo". Sociolinguistic Studies, 8(2): 273-291.

Bonvillain, Nancy. (2008): Language, Culture and Communication. The Meaning of Messages. New Jersey: Prentice Hall. 
Brown, Roger (1958): Words and Things. An Introduction to Language. Illinois: The Free Press/The MacMillan Company.

Braunmüller, Kurt and Julianne House (2009): Convergence and Divergence in Language Contact Situations. Amsterdam: John Benjamins Publishing Company.

Bullock, Barbara and Almeida Jaqueline Toribio (2009): The Cambridge Handbook of Linguistic Code-Switching. Cambridge: Cambridge University Press.

Callahan, Laura (2004): Spanish/English Codeswitching in a Written Corpus.Amsterdam: John Benjamins Publishing Company.

Clyne, Michael (2003): Dynamics of Language Contact: English and Immigrant Languages. Cambridge: Cambridge University Press.

Cortés-Conde, Florencia and Diana Boxer (2002): "Bilingual word-play in literary discourse: The creation of relational identity." Language and Literature, 11(2): 137-151.

Coulmas, Florian (2005): Sociolinguistics: The Study of Speakers' Choices. Cambridge: Cambridge University Press.

Culpeper, Jonathan (2014): Language and Characterization. People in Plays and Other Texts. Hoboken: Taylor and Francis.

Curell, Clara et al. (2009): "Por un glosario de hispanismos en la Literatura de Viajes". In C. Solé i Castells, M. Parra, P. Solá, M.C. Figuerola, eds., Texto y sociedad en las letras francesas y francófonas. Universitat de Lleida, 634-641.

http://dialnet.unirioja.es/servlet/oaiart?codigo=3711598. [Accessed 21 Jan. 2017].

Curell, Clara and Cristina G. de Uriarte (2001): "Hispanismos en los libros de viaje franceses del siglo XVIII". In I. Uzcanga, E. Llamas and J.M. Pérez, eds., Presencia y renovación de la lingüística francesa. Salamanca: Ediciones Universidad de Salamanca, 99-107.

Eastman, Carol M. (1992): Codeswitching. Clevedon: Multilingual Matters.

Flores Ohlson, Linda (2008): 'Soy el brother de dos lenguas.' El cambio de código en la música popular contemporánea. Acta Universitatis Gothoburgensis. Göteborgs Universitet. Romanica Gothoburgensia 55.

Gardner-Chloros, Penelope (1991): Language Selection and Switching in Strasbourg. Oxford: Clarendon Press.

Gardner-Chloros, Penelope (2015): “Code switching - where next?" Paper presented for a Plenary Session at the International Conference on Bilingualism, held at the University of Malta, 23-25 March.

Giles, Howard and Smith, Philip (1979): "Accommodation theory: Optimal levels of convergence". In H. Giles and R. N. St. Clair, eds., Language and Social Psychology.Oxford: Basil Blackwell,45-65.

Giménez-Eguibar, Patricia and De los Heros, Susana (2016): "La alternancia lingüística en los diálogos de East Los Angeles High.Una forma de representación mediática con función afiliativa de la latinidad". In D. Dumitrescu and D. Bravo, eds., Roles situacionales, interculturalidad y multiculturalidad en encuentros en español. Buenos Aires: Editorial Dunken, 31-54.

González-Cruz, María-Isabel (1995): La convivencia anglo-canaria. Estudio sociocultural y lingüístico, 1880-1914. Las Palmas de Gran Canaria: Cabildo Insular de Gran Canaria.

González-Cruz, María-Isabel (2002): Notas para una bibliografía inglesa sobre Canarias. La Laguna: Instituto de Estudios Canarios / Universidad de La Laguna.

González-Cruz, María-Isabel (2011a): "Hispanismos y canarismos en los textos de dos viajeras inglesas decimonónicas". Revista de Filología de la Universidad de la Laguna, 29: 81-99. 
González-Cruz, María-Isabel (2011b): "Exploring the Canarian contribution to Hispanicisms in English". Revista Alicantina de Estudios Ingleses, 24: 131-152.

González-Cruz, María-Isabel (2013): "Hispanismos y canarismos en un corpus de textos ingleses sobre Canarias.” LEXIS. Revista de Lingüistica y Literatura, 37(2): 229-267.

González-Cruz, María-Isabel (2014): "Nuevos registros para la bibliografía en lengua inglesa sobre Canarias: siete relatos de viaje, dos guías turísticas, una obra de ficción y un estudio lingüístico." Anuario de Estudios Atlánticos, 60: 599-641.

González-Cruz, María-Isabel (2015): "Love in Paradise: Visions of the Canaries in a corpus of popular romance fiction novels". Oceánide. Journal of the Spanish Society for the Study of Popular Culture SELICUP7, http://oceanide.netne.net/articulos/art7-4.pdf

González-Cruz, María-Isabel (2017): "Conciencia sociolingüística e hispanismos en un corpus de novela rosa inglesa." SOPRAG Pragmática sociocultural / Sociocultural Pragmatics, 5(2): 125-149. https://doi.org/10.1515/soprag-2017-0014

González Cruz, $\mathrm{M}^{\mathrm{a}}$ Isabel and $\mathrm{M}^{\mathrm{a}}$ del Pilar González de la Rosa (2006): "Language and travel: Spanish vocabulary in British travel books." Tesserae. Journal of Iberian and Latin American Studies, 12(2-3): 203-217.

González Cruz, $\mathrm{M}^{\mathrm{a}}$ Isabel and $\mathrm{M}^{\mathrm{a}}$ del Pilar González de la Rosa (2007): El viaje lingüístico: una aproximación sociolingüística a la literatura de viajes". In J. M. Oliver, C. Curell, C. G. Uriarte and B. Pico, eds., Escrituras y reescrituras del viaje. Miradas plurales a través del tiempo y de las culturas. Bern: Peter Lang, 235-251.

Grosjean, François (1982): Life with Two Languages. An Introduction to Bilingualism. Cambridge (Massachusetts): Harvard University Press.

Gumperz, John Joseph (1992): Discourse Strategies. Cambridge: Cambridge University Press.

Haugen, Einar (1956): "Bilingualism in the Americas: A bibliography and research guide". Publications of the American Dialect Society 26. University of Alabama Press.

Heller, Monica, ed. (1988): Codeswitching: Antropological and Sociolinguistic Perspectives. New York: Mouton de Gruyter.

Heller, Monica (1992): "The politics of codeswitching and language choice". Journal of Multilingual and Multicultural Development, 13(1-2): 123-142.

Heredia, Roberto R. and Jeanette Altarriba (2001): "Bilingual language mixing: Why do bilinguals code-switch?” Current Directions in Psychological Science, 10(5): 164-172.

Jacobson, Rodolfo, ed. (1998): Codeswitching Worldwide. Berlin and New York: Mouton de Gruyter.

Jacobson, Rodolfo (2001): Codeswitching Worldwide II. Berlin and New York: Mouton de Gruyter.

Jackson, Jane (2014): Introducing Language and Intercultural Communication. London and New York: Routledge.

Jiménez Hurtado, Catalina (2011): Léxico y pragmática. Bern: Peter Lang.

Jonsson, Carla (2010): "Functions of code-switching in bilingual theater: An analysis of three Chicano plays". Journal of Pragmatics, 42(5): 1296-1310.

Kanellos, Nicolás (2003): Hispanic Literature of the United States: A Comprehensive Reference. Wesport, CT: Greenwood Publishing.

Keller, Gary (1984): "How Chicano authors use bilingual techniques for literary effect". In E. García et al., eds., Chicano Studies: A Multidisciplinary Approach. New York: Teachers College, 171-192. 
Kecskes, Istvan (2010): "Formulaic language in English Lingua Franca". In P. Hanks and R. Giora, eds., Metaphor and Figurative Language: Critical Concepts in Linguistics. London and New York: Routledge.

Khoutyz, Irina (2009): “Anglicisms as a means of pragmatic marking”. Scientific Bulletin of Politehnica University of Timisoara,8(1-2): 5-11.

Lipski, John M. (1982): "Spanish English language switching in speech and literature - theories and models". The Bilingual Review, 9(3): 191-212.

Lipski, John M. (2005): "Codeswitching or Borrowing? No sé so no puedo decir, you know". In L. Sayahi and M. Westmoreland, eds., Selected Proceedings of the Second Workshop on Spanish Sociolinguistics. Somerville, MA: Cascadilla Press, 1-15.

L. Sayahi and M. Westmoreland (2014): "Spanish-English codeswitching among low-fluency bilinguals: Towards an expanded Typology". Sociolinguistic Studies,8:23-55.

Milroy, Lesley and Pieter Muysken, eds. (1995): One Speaker, Two Languages. CrossDisciplinary Perspectives on Code-Switching. Cambridge: Cambridge University Press.

Montes-Alcalá, Cecilia (2000a): "Written code-switching: Powerful bilingual images". In R. Jacobson, Codeswitching Worldwide II. Berlin and New York: Mouton de Gruyter, 59-74.

Montes-Alcalá, Cecilia (2000b): "Attitudes towards oral and written code-switching in Spanish-English bilingual youth". In A. Roca, ed., Research on Spanish in the United States: Linguistic Issues and Challenges. Somerville, MA: Cascadilla Press, 218-227.

Montes-Alcalá, Cecilia (2001): "Oral vs. written code-cwitching contexts in English-Spanish bilingual narratives". In I. de la Cruz, ed., La lingüística aplicada a finales del siglo XX. Ensayos y propuestas, vol. 2. Madrid: Servicio de Publicaciones de la Universidad de Alcalá de Henares, 715-720.

Montes-Alcalá, Cecilia (2005a): Two Languages, One Pen: Sociopragmatic Functions in Written Spanish-English Codeswitching.PhD Thesis. Michigan: Hell \& Howell Information.

Montes-Alcalá, Cecilia (2005b): "Mándame un e-mail: cambio de códigos españolinglés online". In L. Ortiz López and M. Lacorte, eds., Contactos y contextos lingüísticos: El español en los Estados Unidos y en contacto con otras lenguas. Madrid and Frankfurt: Iberoamericana, 173-185.

Montes-Alcalá, Cecilia (2012): "Code-switching in US Latino novels". In M. Sebba, S. Mahootian and C. Jonsson, eds., Language Mixing and Code-Switching in Writing: Approaches to Mixed-Language Written Discourse. London and New York: Routledge, 6888.

Montes-Alcalá, Cecilia (2015): "Code-switching in US Latino Literature: The role of biculturalism". Language and Literature, 24(3): 264-281.

Montes-Alcalá, Cecilia (2016): "Socio-pragmatic functions of codeswitching in Nuyorican and Cuban American literature". In G. Tamargo et al., eds., Spanish-English Codeswitching in the Caribbean and the US. Amsterdam: John Benjamins Publishing Company, 191-213.

Montes Granado, Consuelo (2012): "Code-Switching as a strategy of brevity in Sandra Cisneros' Woman Hollering Creek and other stories". DQR Studies in Literature, 49: 125138.

Moyer, Melisa (1998): "Bilingual conversation strategies in Gibraltar". In P. Auer, ed., Codeswitching in Conversation. London and New York: Routledge, 215-234.

Müller, Katharina B. (2015): "Code-switching in Italo-Brazilian literature from Rio Grande do Sul and Sao Paulo: A sociolinguistic analysis of the forms and functions of literary codeswitching". Language and Literature, 24(3): 249-263.

Muysken, Pieter (2000): Bilingual Speech. Cambridge: Cambridge University Press. 
Myers-Scotton, Carol (1992): "Comparing codeswitching and borrowing." Journal of Multilingual and Multicultural Development,13(1-2): 19-39.

Myers-Scotton, Carol (1993): Social Motivations for Codeswitching. Evidence from Africa. Oxford: Clarendon Press.

Page, Norman (1988): Speech in the English Novel. London: MacMillan.

Pennycook, Alistair (2012): Language and Mobility: Unexpected Places. Bristol: Multilingual Matters.

Pfaff, Carol W. and Laura Chávez (1986): "Spanish/English codeswitching: Literary reflections of natural discourse". In R. von Bardeleben et al., eds., Missions in Conflict: Essays on U.S.Mexican Relations and Chicano Culture. Mainz: Gunter Narr Verlag Tubingen, 229-254.

Poplack, Shana (1980): "Sometimes I'll start a sentence in Spanish Y TERMINO EN ESPAÑOL: Toward a typology of code-switching". Linguistics, 18(7-8): 581-618.

Poplack, Shana and Marjory Meechan (1998): "How languages fit together in codemixing". International Journal of Bilingualism, 2: 127-138.

Romaine, Suzanne (1995): Bilingualism. Oxford: Basil Blackwell.

Romance Writers of America n.d. "About the romance genre". Available at $\mathrm{http} / / / \mathrm{www} . \mathrm{rwa} . \mathrm{org} / \mathrm{p} / \mathrm{cm} / \mathrm{ld} / \mathrm{fid}=578$ [Accessed 19 March 2016].

Sánchez-Palencia Carazo, Carolina (1997): El discurso femenino de la novela rosa en lengua inglesa. Cádiz: Publicaciones de la Universidad de Cádiz.

Sebba, Mark, Shahrzad Mahootian, and Carla Jonsson, eds. (2012): Language Mixing and Code-Switching in Writing: Approaches to Mixed-Language Written Discourse. London and New York: Routledge.

Sebba, Mark (2000): "Writing switching in British Creole". In K. Jones and M. Martin-Jones, eds., Multilingual Literacies: Reading and Writing Different Worlds. Amsterdam: John Benjamins Publishing Company, 171-187.

Shorter Oxford English Dictionary on Historical Principles (2007): Oxford: Oxford University Press.

Söderqvist, Therése (2009): 'All of a sudden me siento tristona.' El cambio de código inglés / español en MySpace. Unpublished MA Thesis. Göteborgs Universitet, Available at https://gupea.ub.gu.se/bitstream/2077/20834/1/gupea_2077_20834_1.pdf. [Accessed 10 May 2016].

Tabouret-Keller, Andrée (1997): "Language and identity". In F. Coulmas, ed., The Handbook of Sociolinguistics. Malden, USA and Oxford, UK: Wiley-Blackwell, 315-326.

Thompson, Gregory L. and Edwin M. Lamboy (2012): Spanish in Bilingual and Multilingual Settings Around the World. Leiden and Boston: Brill.

Valdés-Fallis, Guadalupe (1976): "Code-switching in bilingual Chicano poetry". Hispania, 59: 866-877.

Valdés-Fallis, Guadalupe (1977): "The sociolinguistics of Chicano literature: Towards an analysis of the role and function of language alternation in contemporary bilingual poetry". Punto de contacto, 1(4): 30-39.

Weinreich, Uriel (1979): Languages in Contact. Findings and Problems. New York: Mouton.

Woolard, K.A. (1987): "Code-switching and comedy in Catalonia". International Pragmatics Association Papers in Pragmatics, 1: 106-122.

Wotjak, Gerd (2006): Las lenguas, ventanas que dan al mundo. El léxico como encrucijada ente morfosintaxis y cognición: aspectos semánticos y pragmáticos en perspectiva intra e interlingüistica. Salamanca: Ediciones Universidad de Salamanca. 
Zentella, Ana Celia (1997): Growing up Bilingual. Puerto Rican Children in New York. Oxford: Basil Blackwell. 